\title{
The Impact of Human Activities on Biodiversity Conservation in a Coastal Wetland in Ghana
}

\author{
A. M. Wuver ${ }^{1}$ and D. K. Attuquayefio ${ }^{2 *}$ \\ ${ }^{1}$ Achimota School, P. O. Box AH 11, Achimota-Accra, Ghana \\ ${ }^{2}$ Department of Zoology, University of Ghana, P. O. Box 67, Legon-Accra, Ghana \\ *Corresponding author, E-mail: zoology@ug.edu.gh
}

\begin{abstract}
The study was undertaken at the Muni-Pomadze coastal wetland in the Central Region of Ghana. The wetland, located about 56 km west of Accra, is an important habitat for wildlife of both local and global conservation significance. This study investigated the effects of human activities (e.g. farming, hunting, fuelwood harvesting, etc.) on the environment and biodiversity conservation in the area, as well as the implications of such activities for the future of the "Aboakyer" Festival of the local Effutu people. The festival is an important ecotourist attraction which is of economic and sociocultural significance for the local people and the country at large. The methodology involved interviews with a cross-section of the local people, the organisation of durbars, and focus group discussions (FGD). The results indicated that, among the various human activities undertaken in the area, fuelwood harvesting, bushfire setting, hunting, and farming had the greatest impact on biodiversity conservation through degradation of the wetland over the years. Furthermore, about $95 \%$ of the respondents regarded the "Aboakyer" Festival as a major socioeconomic activity in the area. There, however, appeared to be little awareness of both "western" and traditional methods of wildlife conservation. The following were recommended for the improvement of the current status of the wetland and its sustainable management: (i) enhancement of local participation in biodiversity conservation initiatives, (ii) initiation of public education and awareness campaigns, (iii) integration of traditional and modern knowledge system of biodiversity conservation, (iv) re-afforestation, (v) introduction of alternative forms of biomass energy, (vi) provision of incentive packages for implementing agencies, and (vii) provision of alternative sources of income for the local population.
\end{abstract}

\section{Introduction}

The basic human life-support systems of the biological environment have always been characterised by change, an inevitable consequence of all human land use throughout history (Mather, 1986; IGBP/HDP, 1993). Seemingly "natural" or pristine ecosystems have been altered significantly by humans at some point in the past (Turner et al., 1990). The generally low human populations, practice of sustainable traditional agriculture, fishing, and animal husbandry, as well as limitation of land use to a relatively smaller segment of the population using simple tools on smaller land areas, however, ensured the sustenance of soil fertility without the use of agro-chemicals. Biodiversity conservation was, thus, achieved through environmentallyfriendly traditional human cultural practices and beliefs (Abayie Boaten, 1998; Amlalo et al., 1998). This in turn fostered a close and mutually supportive relationship between humans and biodiversity for tens of thousands of years (McNeely et al., 1995).

In recent times, biodiversity has become easy targets for human over-exploitation due to burgeoning human populations and the quest for a "better life" through improve-ments in science and technology. Biodiversity, therefore, is being exploited at much faster rates than ever before with negative implications for sustainable human livelihood (Turner et al., 1990). Wilson (1992) has stated that biodiversity is facing a decline of crisis proportions which could ultimately lead to mass extinctions in the very near future. In Ghana, increasing evidence indicates that the rate of environmental degradation has increased in recent times (Gyasi et al., 1995), with previously rich forests being converted to savanna woodland and existing savanna woodlands converted into near desert (Hawthorne \& Abu-Juam, 1995). It has been estimated that Ghana's high forest area of 8.2 million hectares at the turn of last century had dwindled to about 1.7 million hectares by the mid-1980s (Hall, 1987), and about one million hectares by the mid-1990s (Forest Services Division, 1996). 


\section{West Africa Journal of Applied Ecology (WAJAE) -ISSN: 0855-4307 \\ Volume 9 (Jan - Jun 2006) \\ www.wajae.org}

Wetlands have been historically considered "wastelands” (Williams, 1993; Ryan \& Ntiamoa-Baidu, 2000) and, therefore, subjected to degradation through dredging, flooding, filling and excavation for various agricultural and industrial uses. In recent times, however, the attraction and value of wetlands as important wildlife habitats, among other uses (e.g. provision of fin and shell fish, salt, thatch, wood, etc.) (Sather \& Smith, 1984; Ryan \& Ntiamoa-Baidu, 2000) have been increasingly recognised. Coastal wetlands are especially important as nutrient-rich habitats for fish spawning and nursery (Ntiamoa-Baidu \& Gordon, 1991).

The Muni-Pomadze wetland in the Central region of Ghana, is one of five internationally-recognised coastal wetlands (Ramsar sites) under the Convention on Wetlands of International Importance (Ramsar Convention), because of its importance as a breeding and nesting site for migratory and resident waterbirds, insects, and terrestrial vertebrates (Collar et al., 1994; Ryan \& Attuquayefio, 2000). The wetland is particularly important to the local Effutu people, serving as their traditional hunting grounds, especially during their annual "Aboakyer" Festival. In recent times, the previously diverse fauna (e.g. bushbucks, leopards, antelopes, lions, mongooses, etc.) of the area has dwindled, with some of the animals (e.g. lions), presumed locally extinct or existing in very low numbers (Ryan \& Attuquayefio, 2000).

Current evidence indicates that the degradation of the wetland could be largely attributable to neglect and unsustainable human activities (e.g. bushfire setting, hunting, farming, fuelwood harvesting, estate development, etc.) (Ntiamoa-Baidu \& Gordon, 1991; Ryan \& Ntiamoa-Baidu, 1998) over the years. This is against the background of the wetland being particularly vulnerable to degradation because of its more extensive (98\%) dry land coverage (Amatekpor, 1994) than the other coastal wetlands in Ghana. The current situation, if allowed to continue, is likely to result in biodiversity loss from the wetland, consequently diminishing both the local and international significance of the "Aboakyer” Festival.

The main objectives of this study were (i) to investigate the impact of various human activities (bushfire setting, hunting, fuelwood gathering, and farming) on biodiversity conservation (abundance and diversity of flora and fauna) in the wetland, and (ii) to obtain useful data/information to enable recommendations to be made regarding the better management of the wetland. Ultimately, it is hoped to sustain the annual Aboakyer Festival through the improvement of its ecotourist potential and, consequently, the economic well-being of the local people.

Study area

\section{Materials and methods}

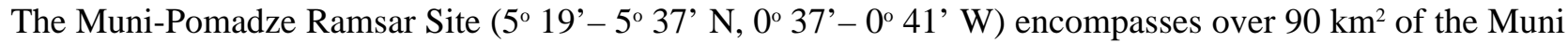
Lagoon watershed located near Winneba in the Central Region (Fig. 1), about $56 \mathrm{~km}$ west of Accra. The wetland is bounded on the north by the Yenku A Forest Reserve established in 1937 (Hawthorne \& AbuJuam, 1995), on the south by the Atlantic Ocean, to the west by the Mankwaafa, Brounye and Boaku rivers, and to the east by the River Ayensu and Pratu stream (Fig. 1). The area falls within the coastal savanna vegetation zone of Ghana, characterised by a low mean annual bimodal rainfall of about $854 \mathrm{~mm}$. The major rainy season starts from March/April to July/August with peak precipitation in June, while the minor season runs from September to November. The main dry season runs from December to March, with the minor dry season running from August to September. Mean annual temperature ranges from $24{ }^{\circ} \mathrm{C}$ in August to $29^{\circ} \mathrm{C}$ in March, and relative humidity (RH) ranges between $75-80 \%$. 


\section{West Africa Journal of Applied Ecology (WAJAE) -ISSN: 0855-4307 \\ Volume 9 (Jan - Jun 2006) \\ www.wajae.org}

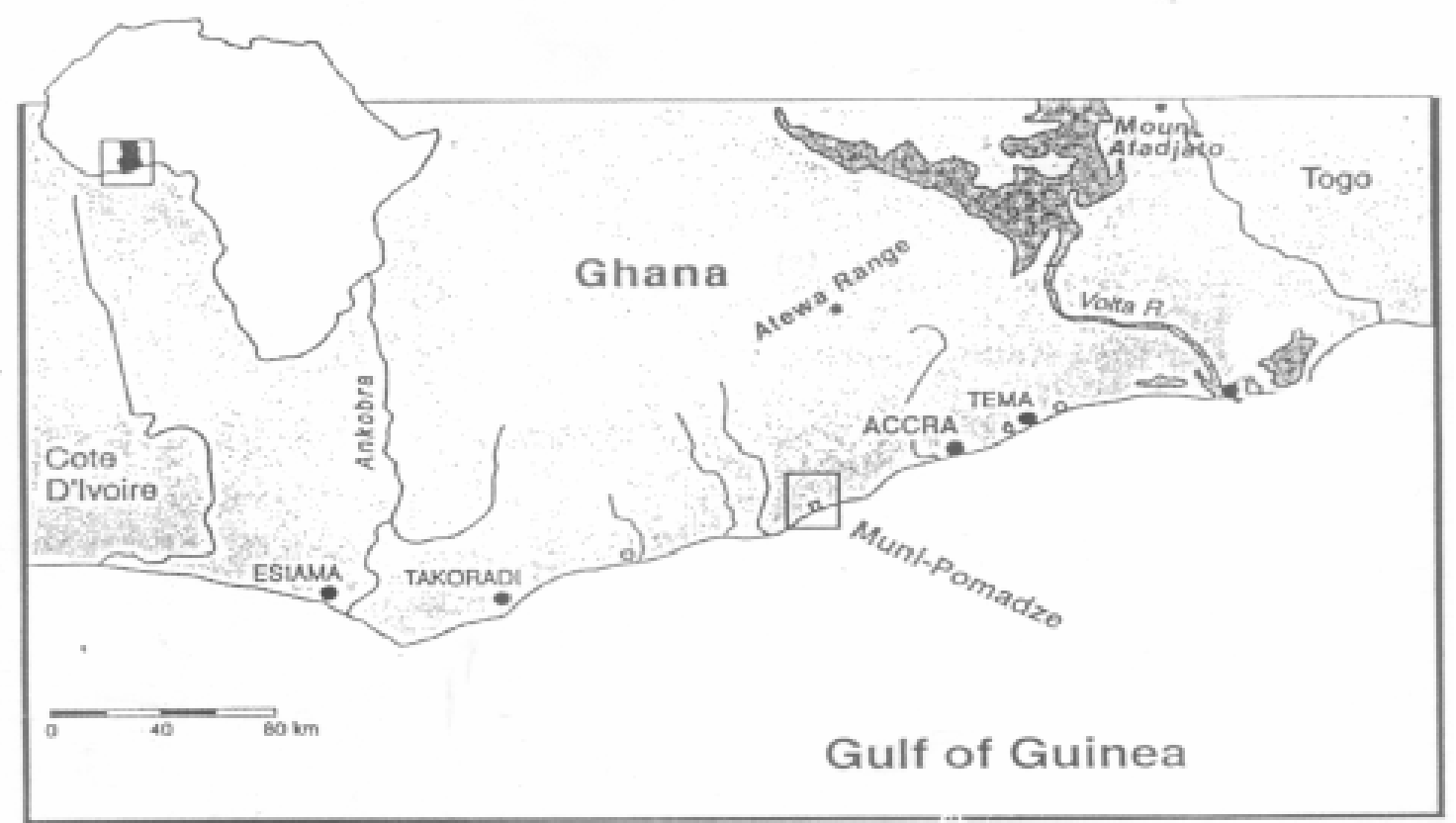

Fig. 1. Location of Muni-Pomadze Ramsar Site

The vegetation of the wetland is southern marginal forest, comprising mainly of grassland, thicket islands and savanna trees (Hall \& Swaine, 1981). Dominant grass species include Andropogon gayanus, Hetero-pogon contortus, Panicum maximum, and Sporobolus pyramidalis. About $40 \%$ of the area was converted into Eucalyptus, Azadirachta indica (neem), and teak plantations when parts of the area were designated as forest reserves (Yenku A and B). The major human activities in the wetland are farming and artisanal fishing (marine and lagoon). Other activities include hunting, sand-winning, charcoal burning, crafts, salt and clay mining, alcohol distillation, quarrying, and trading (Wyllie, 1968). Maize and cassava are the main cultivated crops. There are 11 human settlements in the wetland, the largest being Winneba, with a population of 27,000 people (Grimble et al., 1998).

\section{Administration of questionnaires}

A total of 120 questionnaires were administered in the four closest settlements to the wetland and lagoon, whose inhabitants were expected to use the resources in the area more often: Winneba township (45 questionnaires) and the villages of Onyadze (33 questionnaires), Bewadze (22 question-naires) and Mankoadze (20 questionnaires). The respondents were of various age-groups, religious denominations, occupations and educational backgrounds. Visits to the settlements followed Ghanaian traditions and customs, with the chief and elders being first briefed on the survey objectives with the accompanying customary drinks. Most of the questionnaires were individually administered, and the questions explained to the respondents with the help of coloured illustrations of the animals. The respondents were allowed ample time to complete the questionnaires. As far as possible, the questionnaires were administered on taboo and communal labour days or weekends in order to keep disruptions of farm work or other socio-economic activities of the inhabitants to the barest minimum.

Focus group discussions (FGDs) and durbars

Focus group discussions were organised to obtain direct first-hand information through spontaneous responses from the respondents, most of whom were poorly-educated, and, therefore, could not express 


\section{West Africa Journal of Applied Ecology (WAJAE) -ISSN: 0855-4307 \\ Volume 9 (Jan - Jun 2006) \\ www.wajae.org}

themselves well in English. The District Wildlife Officer and the Fire Officer were present during these forums. The durbars involved the chief, traditional elders, Assemblyman, stake-holders and/or opinion leaders in each of the communities inhabiting the wetland. They were organised to obtain data which could not otherwise have been obtained from the questionnaires due to fear of prosecution and/or shyness on the part of some respondents.

Collection of meteorological and bushfire data

Meteorological data for the study site were obtained from the Meteorological Services Department Headquarters near Legon, while bush fire data were obtained from the national, regional, and district fire offices in Accra, Cape Coast and Winneba, respectively.

\section{Respondent statistics}

\section{Results}

The respondents, a little more than half (54\%) of which were males, covered a wide range of age-groups, with the youngest being 14 years old, and the oldest claimed to be 130 years old (unconfirmed). The dominant age-group (29\%) was 40-49 years while only 4\% were below 20 years of age (Table 1). About $26 \%$ of respondents lacked any formal education, but as many as $72.5 \%$ had had primary, middle or secondary education (JSS and SSS). Only one respondent $(0.8 \%)$ had received university education. Crop farming was by far the dominant occupation (63.3\%), but about 30\% of respondents claimed to have been involved in one or more secondary occupations. Majority of the respondents (80\%) were Christians, while Muslims and African traditionalists were equally represented (Table 1).

TABLE 1

\section{Respondent statistics}

Parameter

Sex

Male

Female

Age-Groups (Years)

Less than 20

20-29

$30-39$

40-49

50-59

More than 60

Education

No Formal education (illiterate)

Primary/middle school

Secondary school (JSS/SSS)

Tertiary education (University)

Occupation

Crop farming $\quad 63.3$

Hunting $\quad 9.2$

Teaching $\quad 8.3$

Fishing $\quad 6.7$

Trading $\quad 6.7$

Fuelwood harvesting $\quad 4.1$

Livestock raising $\quad 1.7$

Religion

Christianity
Percentage of

Respondents

54.0

46.0

4.2

23.3

29.2

13.3

9.2

26.7

55.0

17.5

0.8

3




\section{West Africa Journal of Applied Ecology (WAJAE) -ISSN: 0855-4307 \\ Volume 9 (Jan - Jun 2006) \\ www.wajae.org}

Islamic $\quad 10.0$

African traditionalist $\quad 10.0$

Human activities

Bushfires. During the study period, 15 major bushfires were recorded in the Central Region, out of which seven occurred in the Awutu-Efutu-Senya District, and six occurred in the study area alone. It should be noted, however, that not all bushfires are reported to the National Fire Service. Vegetation burning in the study area was observed from late November to early February. Almost all the bushfires recorded (96\%) were human-caused (anthropogenic), out of which $67.4 \%$ were deliberately set. Deliberate bushfires were set either by hunters (92.1\%) or farmers (7.9\%) clearing vegetation on land for cultivation. Dropping of cigarette butts constituted the main cause (67.9\%) of the accidental bushfires, followed by palm wine tapping and on-farm cooking in that order. Most (61.5\%) of the farmer-respondents set the fires once a year, usually on afternoons when high temperatures promote rapid or easy burning. Majority (92.4\%) of such fire-setters attempted some form of fire control, while the rest thought it was unsafe to do so. About twothirds of respondents (70\%) thought bushfires should be discouraged, because of their detrimental effects on the environment (Table 2).

TABLE 2

Bushfires and biodiversity conservation

$\begin{array}{lr}\text { Parameter } & \begin{array}{r}\text { Percentage } \\ \text { occurrence }\end{array} \\ \text { Sources of bushfire } & \\ \text { Anthropogenic } & 96.0 \\ \text { Natural } & 4.0 \\ \text { Sources of anthropogenic } & \\ \text { bushfires } & 67.4 \\ \text { Deliberate } & 32.6 \\ \text { Accidental } & \\ \text { Sources of deliberate bushfires } & 92.1 \\ \text { Hunting } & 7.9 \\ \text { Vegetation clearing for cultivation } & 67.9 \\ \text { Sources of accidental bushfires } & 18.8 \\ \text { Dropping of cigarette butts } & 13.3 \\ \text { Palm-wine tapping } & \\ \text { On-farm cooking } & 65.1 \\ \text { Time of bushfire setting } & 34.9 \\ \text { Afternoon } & \\ \text { Other } & 92.4 \\ \text { Attempts to control bushfire } & 7.6 \\ \text { Yes } & \\ \text { No } & 30.0 \\ \text { Benefits of bushfires } & 70.0 \\ \text { Yes } & \end{array}$

Hunting. Of the 120 respondents, $35.6 \%$ of the males and $11.3 \%$ of females were hunters. Majority of the hunter-respondents (71.1\%) were inhabitants of the two largest settlements in the study area, Winneba and Mankoadze. Seventy-nine percent of the hunters had been hunting for less than 20 years, while about $8 \%$ had hunted for more than 30 years (Table 3). 
West Africa Journal of Applied Ecology (WAJAE) -ISSN: 0855-4307

Volume 9 (Jan - Jun 2006)

www.wajae.org

TABLE 3

Hunting and biodiversity conservation

Parameter

Percentage of respondents

Gender and hunting

Male hunter-respondents $\quad 35.6$

$\begin{array}{ll}\text { Female hunter-respondents } & 11.3\end{array}$

Settlement of hunter-respondents

Winneba

39.4

Mankoadze

31.7

Bewadze

15.7

Onyadze

13.2

Number of years spent hunting

Less than 20

79.0

20-30

13.1

More than 30

Hunting as an activity

$\begin{array}{ll}\text { Secondary occupation } & 60.0\end{array}$

Primary occupation

(professional)

Hunting strategy

Individual hunting

64.6

Group hunting

35.4

(average 5 hunters/group)

Hunting tools

Shotguns

85.4

Locally-manufactured traps

12.2

Spears

2.4

Hunted animals

$\begin{array}{ll}\text { Grasscutters (T. swinderianus) } & 27.0\end{array}$

Duikers (Cephalophus spp.) $\quad 26.0$

Giant rats (C. gambianus) $\quad 14.0$

Bushbucks (T. scriptus) $\quad 9.0$

$\begin{array}{ll}\text { Others (mongooses, squirrels, } & 24.0\end{array}$ monkeys, francolins, hares, etc.)

Reports of reduced catches

Yes $\quad 70.0$

No $\quad 30.0$

Reasons adduced for reduced catches

Hunting pressure 


\section{West Africa Journal of Applied Ecology (WAJAE) -ISSN: 0855-4307 \\ Volume 9 (Jan - Jun 2006) \\ www.wajae.org}

Bushfires

Habitat change

Scarcity of animal
33.3

16.7

3.2

Occasional hunters constituted $60.0 \%$, while the rest hunted professionally. About $35 \%$ of the hunters did so in groups averaging five hunters of both sexes. Much of the hunting (64.6\%) was undertaken individually, because group hunting was considered illegal, dangerous, and prone to controversy and litigation over meat sharing among members. Hunting was undertaken mostly with shotguns (85.4\%), but locally-manufactured traps and spears were also used (Table 3).

The commonest animals hunted (in order of importance) were grasscutters (27\%), duikers (26\%), giant rats (14\%), bushbucks (9\%), but mongooses, monkeys, squirrels, francolins, hares, and civets were also occasionally captured. About two-thirds of the respondents (69\%) reported a reduction in their catches in recent times, which were attributed largely to over-hunting (46.7\%), and bushfires (38.3\%). Habitat change and scarcity of bushmeat animals in the area were also thought to be contributory factors (Table 3).

Fuelwood harvesting. The main source of energy for the people was fuelwood, which was used by $81.7 \%$ of respondents. Other energy sources were LPG, charcoal, kerosene, and electricity. Fuelwood is the energy source of choice, because of its availability, relative cheapness, and ease of use. There were slightly more (51.6\%) female fuelwood users than males, and $65.0 \%$ of the farmer-respondents used fuelwood. Only about $2 \%$ were professional fuelwood collectors.

Seventy percent of fuelwood users harvested it from the wild, 19.7\% bought it from the market while 5.0\% collected them from their farms after burning (Table 4). About two-thirds (70\%) of fuelwood collectors did so once or twice a week, while the rest did so more than twice a week. Seventy percent of respondents collected fuelwood once or twice a week, while the rest did so more than twice a week. Previously, medium-sized fuelwood (diameter 10-14 cm) was collected by $57.8 \%$ of respondents, while small-sized ones were collected by $22.2 \%$ of respondents, and large-sized ones $(15-19 \mathrm{~cm})$ collected by $20.0 \%$ of respondents. Currently, however, $75.7 \%$ of respondents collect only small-sized fuelwood, and $24.3 \%$ collect only medium-sized fuelwood. No large-sized fuelwood is currently being harvested (Table 4). Because of reduced availability of the preferred large-sized and good-quality fuelwood (e.g. Cassia sp., Azadirachta indica and Zanthoxylum xantholoides) the local residents are compelled to use dried coconut fronds.

TABLE 4

Fuelwood harvesting and biodiversity conservation

Parameter

Use of fuelwood as energy

source

Yes

No

Gender and fuelwood use

Male

Female
Percentage of

respondents

81.7

18.3

48.4

51.6

Volume 9 (Jan - Jun 2006)

Page 7 of 14 
West Africa Journal of Applied Ecology (WAJAE) -ISSN: 0855-4307

Volume 9 (Jan - Jun 2006)

www.wajae.org

\begin{tabular}{ll}
$\begin{array}{l}\text { Fuelwood harvesting as an } \\
\text { occupation }\end{array}$ & \\
$\quad$ Secondary (occasional) & 98.0 \\
Primary (professional) & 2.0 \\
& \\
Source of fuelwood & 70.0 \\
$\quad$ Harvesting from wild & 19.7 \\
Buying from market & 5.0 \\
Collection from farms after burning & 5.3 \\
Other & \\
& \\
Frequency of fuelwood collection & 70.0 \\
$\quad$ Once/twice a week & 30.0 \\
More than twice a week & \\
Previous sizes of fuelwood collected & \\
Medium-sized (10-14 cm diameter) & 57.8 \\
$\quad$ Small-sized (<10 cm diameter) & 22.2 \\
Large-sized (15-19 cm diameter) & 20.0 \\
Current sizes of fuelwood collected & \\
Medium-sized (10-14 cm diameter) & \\
Small-sized (<10 cm diameter) & 24.3 \\
Large-sized (15-19 cm diameter) & 75.7 \\
\hline
\end{tabular}

Farming. Farming was undertaken on both subsistence (62.2\%) and commercial (37.8\%) bases. Males constituted $62.0 \%$ of farmer-respondents. Land for cultivation was normally prepared manually (80\%) either by individual farmers $(72.4 \%)$ or by farming groups $(27.6 \%)$ (Table 5). There was little mechanised farming. About $23.3 \%$ of the farmers had farm sizes above 5 ha (large), but majority of the farms were (1-5 ha). Main crops cultivated were cereals and vegetables (79\%), while about $2.5 \%$ of respondents cultivated trees (e.g. Eucalyptus sp., Cassia sp., etc.). About two-thirds of the farmers (66.0\%) thought that their activities had no effect on the wildlife of the area (Table 5).

TABLE 5

Farming and biodiversity conservation

Parameter

Percentage of
respondents

Type of farming

Subsistence

62.2

Commercial

37.8

Gender and farming

Male

62.0

Female

38.0

Land preparation for cultivation

Manual

80.0

Mechanised

20.0

Types of mechanised farming

Volume 9 (Jan - Jun 2006)

Page 8 of 14 


\section{West Africa Journal of Applied Ecology (WAJAE) -ISSN: 0855-4307 \\ Volume 9 (Jan - Jun 2006) \\ www.wajae.org}

$\begin{array}{lr}\text { Individual } & 72.4 \\ \text { Farming groups } & 27.6 \\ \text { Size of farms } & \\ \quad \text { Small (1-5 ha) } & 76.7 \\ \text { Large ( } 5 \text { ha) } & 23.3 \\ & \\ \text { Crops cultivated } & 79.0 \\ \quad \text { Cereal and vegetables } & 2.5 \\ \text { Trees (Eucalyptus, Cassia, etc.) } & 18.5 \\ \quad \text { Other } & \\ & \\ \text { Effect of farming on wildlife } & 34.0 \\ \quad \text { Yes } & 66.0 \\ \text { No } & \end{array}$

\section{The "Aboakyer" festival and conservation}

A little less than two-thirds (62.2\%) of the people from the Winneba township belonged to either of two Asafo companies within the Effutu Traditional Area, where the annual "Aboakyer" Festival is celebrated. Majority of such respondents (70\%) were more than 40 years of age. Membership of an Asafo company afforded the individual an opportunity to defend the community, engage in community development activities, and to fraternise with other group members. Reasons adduced for non-membership included litigation among members, chieftaincy disputes, religious incompatibility and age (too young or too old). The two major reasons assigned for recent difficulties in getting catches of the bushbuck (Tragelaphus scriptus), the festival animal, were (i) anger of the gods (60\%) and (ii) environmental degradation (30\%). Other reasons included were the inexperience of Asafo members, and rampant bushfires (Table 6). Majority of the respondents (95.0\%) thought that the Aboakyer Festival was an important ecotourist attraction which also provided an opportunity for family reunions. The others thought that it only enabled conservation of the bushbuck, and afforded an opportunity to thank the gods for their protection over the years (Table 6).

About two-thirds (67.6\%) were aware of traditional methods of biodiversity conservation (e.g. introduction of taboo days, establishment of sacred groves, etc.), which were passed on from generation to generation (oral tradition) through parents and community leaders. Only $1.1 \%$ of the respondents thought that traditional biodiversity conservation was more effective than orthodox or "western" methods (legislation, bye-laws, etc.) (Table 6). The two major reasons assigned for the apparent ineffectiveness of traditional conservation were (i) the influence of "western" religious practices, and (ii) disrespect of the younger generation for traditional authority.

TABLE 6

Aboakyer festival and conservation

Parameter

Membership of Asafo Group

Yes

No

Age and Asafo Group Membership

More than 40 years

Less than 40 years
Percentage of

respondents

62.2

37.8

70.0

30.0

Volume 9 (Jan - Jun 2006)

Page 9 of 14 


\title{
West Africa Journal of Applied Ecology (WAJAE) -ISSN: 0855-4307 \\ Volume 9 (Jan - Jun 2006) \\ www.wajae.org
}

\author{
Reasons for Difficulty in Getting \\ Bushbuck Catches in Recent times \\ Anger of the Gods $\quad 60.0$ \\ Environmental Degradation $\quad 30.0$ \\ Inexperience of Asafo Group $\quad 5.0$ \\ Members \\ Rampant Bushfires \\ 5.0 \\ Importance of Aboakyer for \\ Ecotourism \\ Yes $\quad 95.0$ \\ No $\quad 5.0$ \\ $\begin{array}{ll}\begin{array}{l}\text { Awareness of Traditional Conservation } \\ \text { (Taboos days, sacred groves, etc.) }\end{array} & \\ \quad \text { Yes } & 67.6 \\ \text { No } & 32.4 \\ & \\ \text { Traditional vrs. “western” conservation } & 1.1 \\ \quad \text { Traditional conservation more effective } & 98.9\end{array}$
}

\section{Bushfires}

\section{Discussion}

Bushfires as natural phenomena are beneficial to both the biotic and abiotic components of ecosystems (Afolayan, 1978a). However, indiscriminate and repeated anthropogenic bushfires impact negatively on such ecosystems, and, there-fore, need to be checked. The high incidence of deliberately-set bushfires in the Muni-Pomadze wetland could be explained by the fact that most of the human activities on the wetland required the use of fire as a short-cut to achieving the desired results (e.g. hunting and farming). Another reason for the rampant bushfires in the study area was the inability of the fire-setters to control the fires by using more efficient methods (e.g. creation of fire barriers). Often, the fire-setters used less effective materials like palm fronds and tree branches and essentially abandoned the fires to burn out of control.

Unfortunately, bushfire setters do not often take into consideration the direct (killing through burning) and indirect (clearing vegetation and exposing vulnerable animals to predation) destructive effects on wildlife (Collins, 1960). They rather considered anthropogenic bushfires as beneficial in several ways: (i) driving away dangerous animals like snakes, which shelter in dense vegetation, (ii) enhanced hunting efficiency in shortened grasses and attracting game animals after burning, (iii) destruction of unpalatable grass (e.g. $H$. contortus, Bothriochloa sp., etc.) and stimulating the sprouting of new and more palatable grass for grazing mammals at the beginning of the wet season (Korem, 1985; Happold, 1995).

\section{Hunting}

In Ghana, as in other parts of Africa, wild animals are considered destructive and only good for their meat, and are therefore hunted for protection or as a source of protein for the human population (Asibey, 1965a). Not surprisingly, the grasscutter ( $T$. swinderianus), which is the commonest source of bushmeat in most Ghanaian homes, was also the commonest mammal hunted in the study area. Bushmeat is a popular delicacy in both rural and urban areas of Ghana (Falconer, 1992), as well as a valuable source of protein, especially for rural communities (Asibey, 1986; Ntiamoa-Baidu, 1987). It has been estimated that approxi-mately $75 \%$ of the population consume bushmeat regularly (Asibey \& Child, 1990), and that at least $12 \%$ of the diet of Ghanaians comes from wildlife and game, equivalent to $6 \%$ of total household consumption expenditure (Tutu, 1998). Because bushmeat prices tend to be higher than those of the traditional sources of protein 


\section{West Africa Journal of Applied Ecology (WAJAE) -ISSN: 0855-4307 \\ Volume 9 (Jan - Jun 2006) \\ www.wajae.org}

(goat, sheep, poultry, etc.), and demand is high (Asibey, 1977; Falconer, 1992), commercial bushmeat hunting has been a major economic activity in the study area, leading to an influx of migrant hunters from nearby settlements to hunt the already over-exploited bushmeat animals.

The fewer numbers of older hunters in the area could be a result of the current scarcity of economicallyprofitable game largely due to habitat destruction, which had tended to force them to retire early from the profession because of their inability to travel longer and longer distances in search of bigger and economically more profitable game (e.g. duikers, bushbucks, warthogs, etc.). Unfortunately, the younger hunters, being more prone to disregarding the need for sustainability of the hunting industry, resort to the use of illegal hunting methods (e.g. group hunting, setting bushfires, using chemical poisons, etc.) in flagrant disregard of Wildlife Conservation Regulations.

As expected, shotgun hunting was the most popular method of hunting, because it enabled the killing of larger game within a shorter period, and was, therefore, economically more profitable (more meat with less hunting effort). It was undertaken essentially at night, because the reflection of the tapetum of the eyes of nocturnal animals ("eye-shine”) rendered such animals easy prey for hunters using headlamps. Another reason for the popularity of shot gun hunting was that trapping was considered inefficient and dangerous, since the traps sometimes caught non-target dangerous animals (e.g. snakes), and the trapped target animals could be stolen, often together with the trap.

The World Bank (1999) reported that widespread rural poverty, illiteracy, and hunger have compelled rural populations to exploit natural resources unsustainably for survival. Such populations simply could ill-afford to preserve wildlife for purely aesthetic, cultural or educational reasons. This appears to be the case with the inhabitants of the study area who could only be expected to appreciate wildlife through education and awareness programmes which stress the importance of biodiversity conservation and its role in ultimately increasing food supply (Asibey, 1965b). Against the background that more than $80 \%$ of the population lacked formal education beyond the basic level, this would be quite a daunting task.

\section{Fuelwood harvesting}

According to Korem (1985), fuelwood provides the main energy source for both rural and urban households throughout the entire West African sub-region, with estimates of about $50 \%$ of total energy consumption. Fuelwood plays an important role in human activities like fish smoking and charcoal production in the essentially coastal wetland community. It was apparent from this study that over-exploitation of fuelwood has resulted in a reduction in size of fuelwood harvested, and the use of less-preferred materials like coconut fronds, twigs, cassava sticks, and tree stumps. Some of the reasons for fuelwood over-exploitation in the area include: (i) high costs of alternative energy sources (e.g. LPG, electricity, etc.), (ii) alternative uses of fuelwood for non-domestic purposes like fish smoking, ceramics, pottery, and preparation of "street food", and (iii) widespread cutting of small- and medium-sized branches from wild-growing trees instead of collecting dead fallen wood as pertains in parts of East Africa and West Africa (Korem, 1985), and (iv) production of commercial quantities of charcoal, which is in very high demand in urban areas, because of its lighter weight and slow and hot burning qualities.

The situation has assumed such alarming proportions that even a tree species like Milletia spp. which was previously left intact, because of its soil fertility rejuvenating qualities, was now being harvested for fuelwood. The higher percentage of female fuelwood collectors and users in the study area appeared in keeping with the traditional role of women as "meal preparers" in most rural and urban African communities.

\section{Farming}




\section{West Africa Journal of Applied Ecology (WAJAE) -ISSN: 0855-4307 \\ Volume 9 (Jan - Jun 2006) \\ www.wajae.org}

The large proportion of respondents who did not consider farming activities as threats to biodiversity and environment, as well as a lack of awareness of the direct (source of meat, medicine, etc.) and indirect (pollinators, seed dispersers, etc.) uses of biodiversity to human populations, suggested a rather low priority given to wildlife or environmental awareness among the wetland community. It appeared that farming was undertaken without due consideration to sustainable land use practices, with large tracts of land being cleared for farming and infrastructural development at the expense of valuable wildlife habitat. The important roles of wildlife in the ecosystem food web as pollinators, predators, seed dispersers or prey species of other animals did not seem to have been appreciated by a majority of the local people. An appreciation of such indirect values of wildlife is important to prevent destruction of wildlife habitat through farming and other human activities.

\section{The "Aboakyer" festival and conservation}

Not surprisingly, about $60 \%$ of the pre-dominantly rural and superstitious communities in the study area attributed the difficulty of getting catches of the festival animal, the bushbuck (T. scriptus) to the anger of the gods, rather than the fact that any renewable resource harvested faster than its regeneration rate, was bound to become depleted sooner or later. Ever since bushbucks replaced humans as sacrificial festival animals (Wilson, 1963), they had been caught annually until recently, when in some years the Asafo Companies failed to obtain catches, or could only catch immature animals (Mensah, pers. comm.). Obviously, over-exploitation and habitat destruction have resulted in the dwindling of bushbuck populations over the years.

It is quite surprising that in a community where most individuals were born into a family belonging to an Asafo company, about $60 \%$ of the respondents were not Asafo company members. This situation has serious negative implications for the future of the economically-important "Aboakyer" Festival. The reasons for refusal to join an Asafo Company included (i) incompatible religious beliefs (Asafo companies were considered largely fetish entities deeply steeped in idolatory), (ii) economic conside-rations (lack of time and interest in partici-pating in social/recreational activities in the face of economic hardships), and (iii) rampant chieftaincy disputes (chiefs were actively involved in festival activities). The Effutu traditional area has its fair share of chieftaincy disputes, which had sometimes resulted in cancellation of the annual festival celebrations by the security agencies. Such developments are a deterrent to membership of an Asafo company, especially among the peace-loving younger folk.

\section{Community attitudes toward conservation}

Historically, African societies have had a stable co-existence with wildlife, because of the intrinsic value attached to environ-mental conservation in African cultural practices (Hadley, 1985). It is, therefore, quite disturbing that the younger generation of the study area, which was expected to carry on the traditions left behind by the older generation either through oral tradition or on-the-job training, did not appear to support conservation activities. The dwindling membership of Asafo companies needs to be tackled with all seriousness by encouraging the younger generation to join these companies, which represent a rallying point for conservation activities in the area.

According to Gyasi (1998), the basic principle underlying the use of Ghana's biophysical resources is harmony with the environment and respect for nature. This has necessitated the putting in place of a number of norms, cultural ethics, regulations, laws, taboos/customs, sacred groves, etc.) to ensure the long-term sustainability and conservation of biodiversity. Unfortunately, the colonial centralisation of government had tended to undermine existing customary laws and traditional authority, resulting in such laws being largely ignored (Swift, 1982). The advent of Christianity, formal "western" education and technological advancement have rendered some of these norms and taboos obsolete (Abayie-Boaten, 1998), because they 


\section{West Africa Journal of Applied Ecology (WAJAE) -ISSN: 0855-4307 \\ Volume 9 (Jan - Jun 2006) \\ www.wajae.org}

were considered largely fetish (Adomako et al., 1998). Also, the custodians of the taboos themselves (invariably illiterate fetish priests and traditional rulers) often tended to concentrate on sanctions imposed on offenders, rather than education of their subjects on the need to maintain such taboos.

\section{Conclusion}

From the results of the study, the major human activities that impact on the biodi-versity of the study area were bushfires, hunting, fuelwood harvesting and farming, in order of importance. Hunting pressure has increased over the years, against the back-ground of waning resilience of traditional conservation practices in the study area. To sustain the economically-important Aboakyer Festival as well as biodiversity conservation initiatives in the study area, the following are recommended:

- incorporation of indigenous knowledge, practices and skills into modern methods of conservation through local participation, in conservation initiatives in order to develop sustainable conservation programmes

- initiation of education and awareness programmes targeted at children and the youth, stressing the direct and indirect values of wildlife and the scientific basis of traditional conservation

- integration of both traditional and modern knowledge systems of biodiversity conservation into school curricula

- initiation of afforestation programmes to attract wildlife to the traditional hunting grounds, and protection of such grounds from bushfires and other human activities to enable recovery of bushbuck popula-tions

- encouragement of local inhabitants to harness other forms of biomass energy (e.g. crop residue, organic refuse) in order to reduce pressure on fuelwood

- provision of adequate financial resources for agencies involved in conservation efforts in the wetland to enhance their efficiency and performance

- provision of alternative sources of income for the local people to reduce pressure on the already depleted biodiversity of the wetland

\section{Acknowledgement}

Partial support for the study was provided through fellowship by the Volta River Authority (VRA). to A. M. Wuver. Special thanks also go to Mr Samuel Adu of the Ghana Wildlife Society, for his help in data collection. The co-operation of the community/traditional leaders and local inhabitants of the study area is greatly acknowledged.

\section{References}

Abayie Boaten A. (1998). Traditional Conservation Practices: Ghana's Example. In Biodiversity conservation: traditional knowledge and modern concepts. (D. S. Amlalo, L. D. Atsiatorme, and C. Fiati ed.), pp. 1-6. Proceedings of the Third UNESCO-MAB Regional Seminar on Biosphere Reserves for Biodiversity Conservation and Sustainable Development in Francophone Africa (BRAAF). Cape Coast, 9-12 March, 1997.

Adomako E. E., Adomako J. K. and Bayliss-Smith T. P. (1998) "Conservation by Tradition: The Case of the Guako Sacred Grove”. In Biodiversity conservation: traditional knowledge and modern concepts. (D. S. Amlalo, L. D. Atsiatorme and C. Fiati, ed.). Proceedings of the Third UNESCO-MAB Regional Seminar on Biosphere Reserves for Biodiversity Conservation and Sustainable Development in Francophone Africa (BRAAF). Cape Coast, 9-12 March, 1997.

Afolayan T. A. (1978). Savanna burning in Kainji Lake National Park, Nigeria. E. Afr. Wildlife J. 16: $254-255$.

Amatekpor J. K. (1994). Ghana Coastal Wetlands Management Project: Environmental baseline studies on Muni-Pomadze Ramsar site- soil, landuse and land degradation. Department of Game and Wildlife, Government of Ghana. Document No. GW/ A. 285/SF.2/ 29.

Amlalo D. S., Atsiatorme L. D. and Fiati C. (ed.) (1998). Biodiversity conservation: Traditional knowledge and modern concepts. Proceedings of the Third UNESCO-MAB Regional Seminar on Biosphere Reserves for Biodiversity Conserva-tion and Sustainable Development in Francophone Africa (BRAAF). Cape Coast, 9-12 March, 1997.

Asibey E. O. A. (1965a). Utilisation of wildlife in Ghana. Ghana Fmr. 9 (3): 91-93.

Asibey E. O. A (1965b). Uganda's big game is a major land product. Ghana Fmr. 9 (2): 58-61.

Asibey E. O. A. (1977). Expected effects of land-use patterns on future supplies of bushmeat in Africa South of the Sahara. Environ.Conserv. 4 (1): 43-49. 


\section{West Africa Journal of Applied Ecology (WAJAE) -ISSN: 0855-4307 \\ Volume 9 (Jan - Jun 2006) \\ www.wajae.org}

Asibey E. O. A. (1986). Wildlife as a source of protein in Africa south of the Sahara. Biol. Conserv. 6 (1): 32-39.

Asibey E. O. A. and Child G. S. (1990). Wildlife management for rural development in Sub-Saharan Africa. Unasylva 41: 3-10.

Collar N. J., Crosby M. J., and Stattesfield A. J. (1994). Birds to Watch 2 (The World List of Threatened Birds). Official Source for Birds on the IUCN Red List. Birdlife International, Cambridge, UK.

Collins W. B. (1960). Wildlife conservation in Ghana: Part II. Ghana Fmr. 5 (1): 28-35.

Falconer J. (1992). Non-timber forest products in Southern Ghana. Report to Forestry Services Division of Ghana, Accra.

Forest Services Division (FSD) (1996). Annual Report. Ministry of Lands and Forestry, Accra, Ghana.

Grimble E., Elenbroek W., Willoughby N., Danso E. and Amatekpor J. (1998). Study of develop-ment options for Ghana coastal wetlands, vol. 1 (Main report). Environmental Protection Agency and Natural Resources International Report, Kent.

Gyasi E. A. (1998). Land tenure system and traditional concepts of biodiversity conservation”. In Biodiversity conservation: traditional knowledge and modern concepts. (D. S. Amlalo, L. D. Atsiatorme and C. Fiati, ed.). Proceedings of the Third UNESCO-MAB Regional Seminar on Biosphere Reserves for Biodiversity Conservation and Sustainable Development in Francophone Africa (BRAAF). Cape Coast, 9-12 March, 1997.

Gyasi E. A., Agyepong G. T., Ardayfio-Schandorf E., Enu-Kwesi L., Nabila J. S. and Owusu-Bennoah E. (1995). Production pressure and environmental change in the forest-savanna zone of southern Ghana. Global Environmental Change 5 (4): 355-366.

Hadley M. (1985). Comparative aspects of land use and resource management in savanna environ-ments. In Ecology and management of the world's savannas. (J. E. Tothil and J. J. Mott, ed.). Commonwealth Agricultural Bureau, London.

Hall J. B. (1987) Conservation of forest in Ghana. Universitas 8: 33-42.

Hall J. B. and Swaine M. D. (1981). Geobotany 1. Distribution and ecology of vascular plants in a tropical rain forest: Forest vegetation in Ghana. W. Junk, The Hague, Netherlands.

Happold D. C. D. (1995). The interaction between humans and mammals in Africa in relation to conservation: a review. Biodiver. Conserv. 4: 395-414.

Hawthorne W. D. and Abu-Juam A. M. (1995). Forest protection in Ghana. IUCN/ODA, Cambridge, U.K.

International Geosphere and Biosphere Programme/Human Dimensions Programme ((IGBP/HDP) (1993). Relating land use and global land-cover change. IGBP Report No. 24, HDP Report No. 5, Stockholm.

Korem A. (1985). Bushfire and agricultural development in Ghana. Ghana Publishing Corporation, Tema.

Mather A. S. (1986). Land use. Longman, London, UK.

McNeely J. A., Gadgil M., Leveque C., Padock C. and Redford K. (1995). Human influence on biodiversity. In Global biodiversity assessment. (V. H. Heywood and R. T. Watson, ed.), pp. 771-821. Cambridge University Press, Cambridge.

Ntiamoa-Baidu Y. (1987). West African wildlife: a resource in jeopardy. Unasylva 156: 27-42.

Ntiamoa-Baidu Y. and Gordon C. (1991). Coastal wetlands management plans: Ghana. Environ-mental Protection Council and World Bank. Ghana Environmental Resource Manage-ment Project (GERMP)Report, Accra.

Ryan J. M. and Attuquayefio D. K. (2000). Mammal fauna of the Muni-Pomadze Ramsar site, Ghana. Biodiv. Conserv. 9: 541560.

Ryan J. M. and Ntiamoa-Baidu Y. (ed.) (1998). Studies on the terrestrial fauna of coastal Ramsar sites, Ghana. Ghana Coastal Wetlands Project.

Ryan J. M. and Ntiamoa-Baidu Y. (2000). Biodiversity and ecology of coastal wetlands in Ghana. Biodiv. Conserv. 9: $445-446$.

Sather J. M. and Smith R. D. (1984). An overview of major wetland functions and values. Fish and Wildlife Service, FWS/OBS84/18, Washington DC. 152 pp.

Swift J. (1982) The future of African hunter-gatherers and pastoral peoples. Develop. Change, 13 (2): $159-181$.

Turner B. L., Clark W. C., Kates R. W., Richards J. F., Matthews J. T. and Meyers W. B. (ed.) (1990). The earth as transformed by human action. Cambridge University Press, Cambridge.

Tutu K. (1998). Valuation of Non-timber Forest Products in Bia National Park. In Biodiversity conservation: traditional knowledge and modern concepts. (D. S. Amlalo, L. D. Atsiatorme and C. Fiati, ed.). Proceedings of the Third UNESCO-MAB Regional Seminar on Biosphere Reserves for Biodiversity Conservation and Ssustainable Development in Francophone Africa (BRAAF). Cape Coast, 9-12 March, 1997.

Williams M. (1993). Wetlands: A threatened landscape. Blackball Publishers, Oxford.

Wilson J. (1963). Origin of deer hunt. The Ghanaian 6 (6): 5, 30.

Wilson D. E. (1992) The diversity of life. Belknap, Cambridge, Massachusetts.

World Bank (1999). Annual review on environmental matters: towards environmentally and socially sustainable development. Washington, DC.

Wyllie W. R. (1968). Ritual and social change: A Ghanaian example. Am. Anthropol. 70: 21-33. 